Aquatic Nuisance Species Research Program

\title{
Habitat Preference, Dispersal, and Population Trends of Three Species of Invasive Asian Carps in Tributaries of the La Grange Reach of the Illinois River
}

Michael R. Wilson

July 2012 


\section{Habitat Preference, Dispersal, and Population Trends of Three Species of Invasive Asian Carps in Tributaries of the La Grange Reach of the Illinois River}

Michael R. Wilson

Illinois Natural History Survey

University of Illinois at Urbana-Champaign

Final report

Approved for public release; distribution is unlimited.

Prepared for U.S. Army Corps of Engineers

Washington, DC 20314-1000

Monitored by U.S. Army Engineer Research and Development Center

3909 Halls Ferry Road, Vicksburg, MS 39180-6199 


\section{Abstract}

Asian carps (Ctenopharyngodon idella, Hypophthalmichthys molitrix, and H. nobilis), first introduced into the United States in the 1960s and 1970s, escaped and established reproducing populations in the Mississippi and Illinois River systems by the year 2000. By the mid 1990s, they were appearing in smaller tributaries and streams in Illinois. During the summer of 2009, a drainage-wide survey of the La Grange Reach of the Illinois River was conducted to determine the extent to which these species were utilizing first- through fourth-order streams in this system. Field sampling of 36 sites over a 33,636- $\mathrm{km}^{2}$ area in 2009 produced a total of five grass carp and no other Asian carp specimens, indicating temporary nonresident utilization of small streams. Because of the paucity of Asian carp specimens collected during field work, field data were combined with records from the Illinois Natural History Survey Fish Collection, Illinois Department of Natural Resources survey data, and the Long Term Resource Monitoring Program. These data were subjected to statistical analysis to test for correlation of population trends between the Illinois River mainstem and its associated tributaries. Analysis results revealed a positive relationship between annual mainstem and tributary population trends for grass carp and silver carp, as well as a continually increasing population size for all three species in both mainstem and tributary populations.

DISCLAIMER: The contents of this report are not to be used for advertising, publication, or promotional purposes. Citation of trade names does not constitute an official endorsement or approval of the use of such commercial products. All product names and trademarks cited are the property of their respective owners. The findings of this report are not to be construed as an official Department of the Army position unless so designated by other authorized documents. 


\section{Contents}

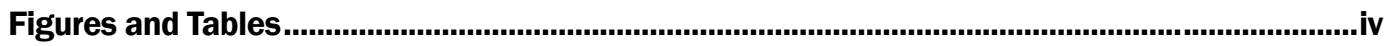

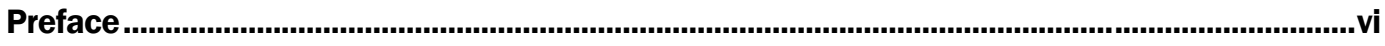

Unit Conversion Factors.........................................................................................................................vii

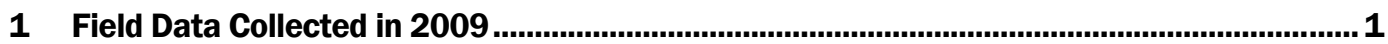

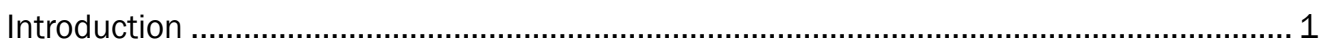

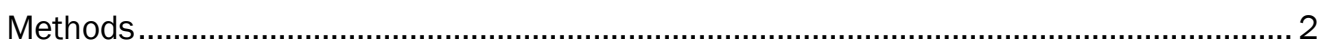

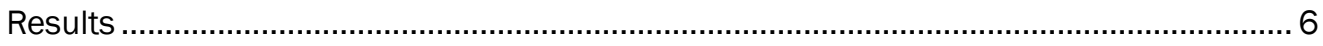

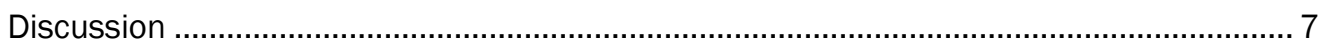

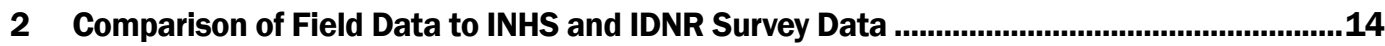

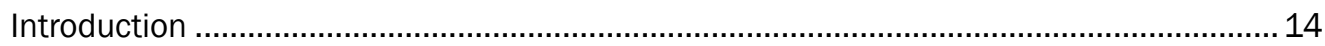

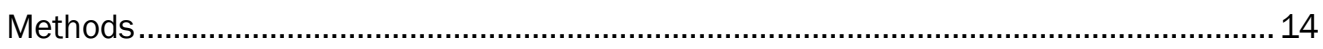

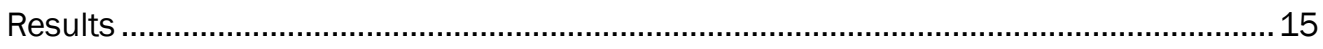

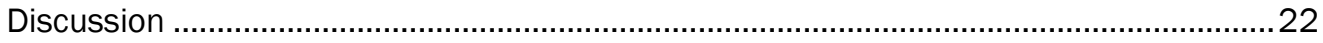

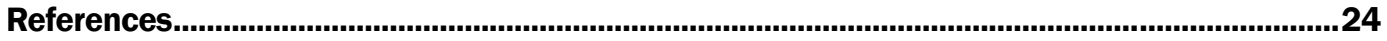

Report Documentation Page 


\section{Figures and Tables}

\section{Figures}

Figure 1. The La Grange Reach of the Illinois River stretches from its northern extent at the Peoria Lock and Dam at Peoria, Illinois to its southern extent at the La Grange Lock and Dam eight miles downstream of Beardstown, Illinois.

Figure 2. Locations of 2009 field sites................................................................................ 5

Figure 3. Quiver Creek sampling site........................................................................................ 8

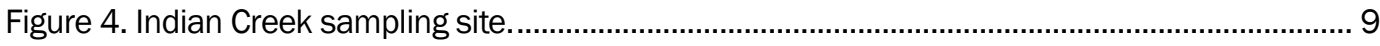

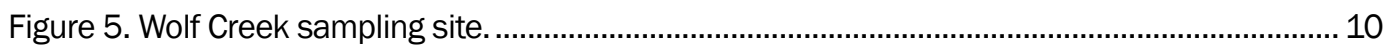

Figure 6. Histogram depicting average annual catch of grass carp in the Illinois River mainstem (maroon) and tributaries associated with the Illinois River (blue).

Figure 7. Histogram depicting average annual catch of bighead carp in the Illinois River mainstem (maroon) and tributaries associated with the Illinois River (blue).

Figure 8. Histogram depicting average annual catch of silver carp in the Illinois River mainstem (maroon) and tributaries associated with the Illinois River (blue).

Figure 9. Scatter plot showing resulting trend line from charting average annual catch of grass carp in the Illinois River mainstem (X-axis) against average annual catch of grass carp in tributaries associated with the Illinois River (Y-axis).....

Figure 10. Scatter plot showing resulting trend line from charting average annual catch of bighead carp in the Illinois River mainstem (X-axis) against average annual catch of bighead carp in tributaries associated with the Illinois River (Y-axis).

Figure 11. Scatter plot showing resulting trend line from charting average annual catch of silver carp in the Illinois River mainstem (X-axis) against average annual catch of silver carp in tributaries associated with the Illinois River (Y-axis).....

\section{Tables}

Table 1. Sampling design for 2009 fieldwork. Six sites were randomly selected from each of six groups of candidate sites, making a total working group of 36 sampling sites. ....

Table 2. Sampling sites at which Asian carps were located, including date, site, county, stream order and species for each location.

Table 3. Habitat characteristics of stream sites at which Asian carps were collected during 2009 fieldwork.

Table 4. Results of Pearson correlation comparing habitat variables with presence of grass carp.

Table 5. Results of logistic regression comparing habitat variables with presence of grass carp.

Table 6. Wilcoxon's signed-ranks test results from comparing annual grass carp population trends for the Illinois River mainstem versus its tributaries.

Table 7. Wilcoxon's signed-ranks test from comparing annual bighead carp population trends for the Illinois River mainstem versus its tributaries. 
Table 8. Wilcoxon's signed-ranks test from comparing annual silver carp population trends for the Illinois River mainstem versus its tributaries.

Table 9. $p$-values returned from Pearson correlation and linear regression analysis comparing mainstem average annual catch numbers against tributary average annual catch numbers. 


\section{Preface}

The work reported herein was conducted as part of the Aquatic Nuisance Species Research Program (ANSRP). The ANSRP is sponsored by Headquarters, U.S. Army Corps of Engineers (HQUSACE) and is assigned to the U.S. Army Engineer Research and Development Center (ERDC) under the purview of the Environmental Lab (EL). Funding was provided under Department of the Army Appropriation Number 96X3122, Construction General. Dr. Linda S. Nelson, EL, was Program Manager, ANSRP. Program Monitor during this investigation was J oseph Wilson, HQUSACE.

Principal Investigator for this study was Michael R. Wilson, Illinois Natural History Survey. Funding was provided by ANSRP, The Illinois Natural History Survey, the Illinois Chapter of the American Fisheries Society, and by the Retzer Research Fund at the University of Illinois. The Illinois Department of Natural Resources issued an Illinois scientific collecting permit. B. Cheek, Z. Rasche, M. Retzer, and A. Zollner assisted with fieldwork. Dr. Mike Retzer and Lisa Kelly-Wilson provided editorial assistance on earlier drafts. The report was prepared by Wilson and Dr. J an J effrey Hoover, Aquatic Ecology and Invasive Species Branch (EE-A), Ecology and Environmental Engineering Division (EEED), EL. The report was reviewed by Dr. J ack Killgore (EE-A) and Dr. Todd Slack (EE-A).

This investigation was performed under the general supervision of Dr. Tim Lewis, Chief, EE-A, EL; Dr. Edmond Russo, Chief, Ecosystem Evaluation and Engineering Division; and Dr. Elizabeth Fleming, Director, EL.

COL Kevin J . Wilson was Commander and Executive Director of ERDC. Dr. J effery P. Holland was ERDC Director. 


\section{Unit Conversion Factors}

\begin{tabular}{|l|c|l|}
\hline Multiply & By & To Obtain \\
\hline degrees Fahrenheit & $(F-32) / 1.8$ & degrees Celsius \\
\hline feet & 0.3048 & meters \\
\hline inches & 0.0254 & meters \\
\hline miles (U.S. statute) & $1,609.347$ & meters \\
\hline
\end{tabular}




\section{Field Data Collected in 2009}

\section{Introduction}

Native to temperate eastern regions of the Union of Soviet Socialist Republics and China (Kolar et al. 2005, Shireman and Smith 1983, Guillory and Gasaway 1978), Asian carps (grass carp, bighead carp, and silver carp) were first introduced in the United States in the late 1960s and early 1970s for aquacultural purposes. Because of its voracious appetite for aquatic macrophytes, the phytophagous grass carp (Ctenopharyngodon idella, Valenciennes 1844) has been introduced into all but a handful of the continental United States (Schofield et al. 2005). As highly efficient planktivores, bighead carp (Hypophthalmichthys nobilis, Richardson 1845) and the closely related silver carp (Hypophthalmichthys molitrix, Valenciennes 1844) were introduced into the United States to help control plankton and algal blooms in aquaculture ponds (Kolar et al. 2005, Schofield et al. 2005, J ennings 1988). Unfortunately, all three species escaped and their subsequent establishment in the lower Mississippi River Drainage System has proven to be a problem on a mammoth scale. Silver carp are arguably the most predominant fish species in the lower half of the Illinois River - a recent study of the La Grange reach of the Illinois River (Sass et al. 2010) found that silver carp, which comprised less than $0.1 \%$ of the total catch for the Long Term Resource Monitoring Program (LTRMP) ${ }^{1}$ in 1998, accounted for nearly $51 \%$ of the total catch only 10 years later. In the summer of 2010, J erde et al. (2010) discovered environmental DNA (eDNA) markers for both bighead and silver carp in the Calumet and Chicago Rivers less than $1 \mathrm{~km}$ downstream from Lake Michigan. These markers give evidence that some fish may have already entered Lake Michigan (J erde et al. 2010). As a result, both the Illinois state and federal governments have spent millions of dollars attempting to bar the entrance of Asian carps into the Great Lakes. According to an informational Website maintained by the Chicago District Office of the U.S. Army Corps of Engineers ${ }^{2}$ (last updated Aug. 7, 2009), as of 2007, \$13.1 million had been

\footnotetext{
${ }^{1}$ Begun in 1987, the Long Term Resource Monitoring Program (LTRMP) is an ongoing program implemented by the U.S. Geological Survey (USGS) in cooperation with five states bordering the Upper Mississippi River System, including Illinois, lowa, Minnesota, Missouri, and Wisconsin, with guidance and overall program responsibility provided by the U.S. Army Corps of Engineers. Information about this program and the data it provides can be found at: www.umesc.usgs.gov/Itrmp.html.

${ }^{2}$ www.Irc.usace.army.mil/projects/fish_barrier/index.html
} 
spent on the construction and operation of two electric fish dispersal barriers in the Chicago Sanitary and Ship Canal at Romeoville, Illinois. Of this amount, \$10.8 million was supplied by the federal government and the remaining $\$ 2.3$ million by the State of Illinois. Pending final approval, this single project has a total budget of just over $\$ 20$ million. On February 17, 2010, at the Asian Carp Regional Coordinating Committee Meeting in Ypsilanti, Michigan, the U.S. Army Corps of Engineers announced plans to construct yet a third fish barrier in the Chicago Sanitary and Ship Canal. Minutes from this meeting can be viewed at www.epa.gov/greatlakes/invasive/asiancarp/asiancarp_feb17_ypsilanti.pdf.

Invasion by these species is not limited solely to the Illinois River mainstem. Adjoining tributaries are also subject to encroachment. Asian carps began appearing in tributary surveys as early as 1990 when a bighead (Illinois Natural History Survey Fish Collection ID\# INHS 27896) was caught in the Kankakee River. In 1998, grass carp were caught in both the Mackinaw (Illinois Department of Natural Resources [IDNR] ID\# 5547) and Spoon (IDNR ID\# 5436) Rivers. The first silver carp record comes from Macoupin Creek in 2001 (IDNR ID\# 13078). Later records reflect the presence of all three species in smaller creeks and streams well away from the Illinois River.

Species diversity (Resh et al. 1988) and species richness (Townsend et al. 1997, Minshall et al. 1985) have long been associated with an ecosystem's ability to tolerate disturbance. Because small streams are less diverse than rivers (Schlosser 1987), they are much more sensitive to disturbance (Meyer et al. 2007) than are rivers. Therefore, the proportion of Asian carps in small streams would only need to be a fraction of that in the river mainstem to have significant detrimental impact. Based on this information, a drainage-wide survey of first- through fourth-order streams of tributaries to the LaGrange reach of the Illinois River were conducted to determine whether or how extensively these species utilize the watershed.

\section{Methods}

Study area-The La Grange Pool (Figure 1) is an 80-mile segment of the Illinois River between the Peoria Lock and Dam (L \& D) to the north and the La Grange L \& D to the south (Irons et al. 2007). This investigation focused on the tributaries contained within this segment's drainage region, covering an area of approximately 33,636 km². 


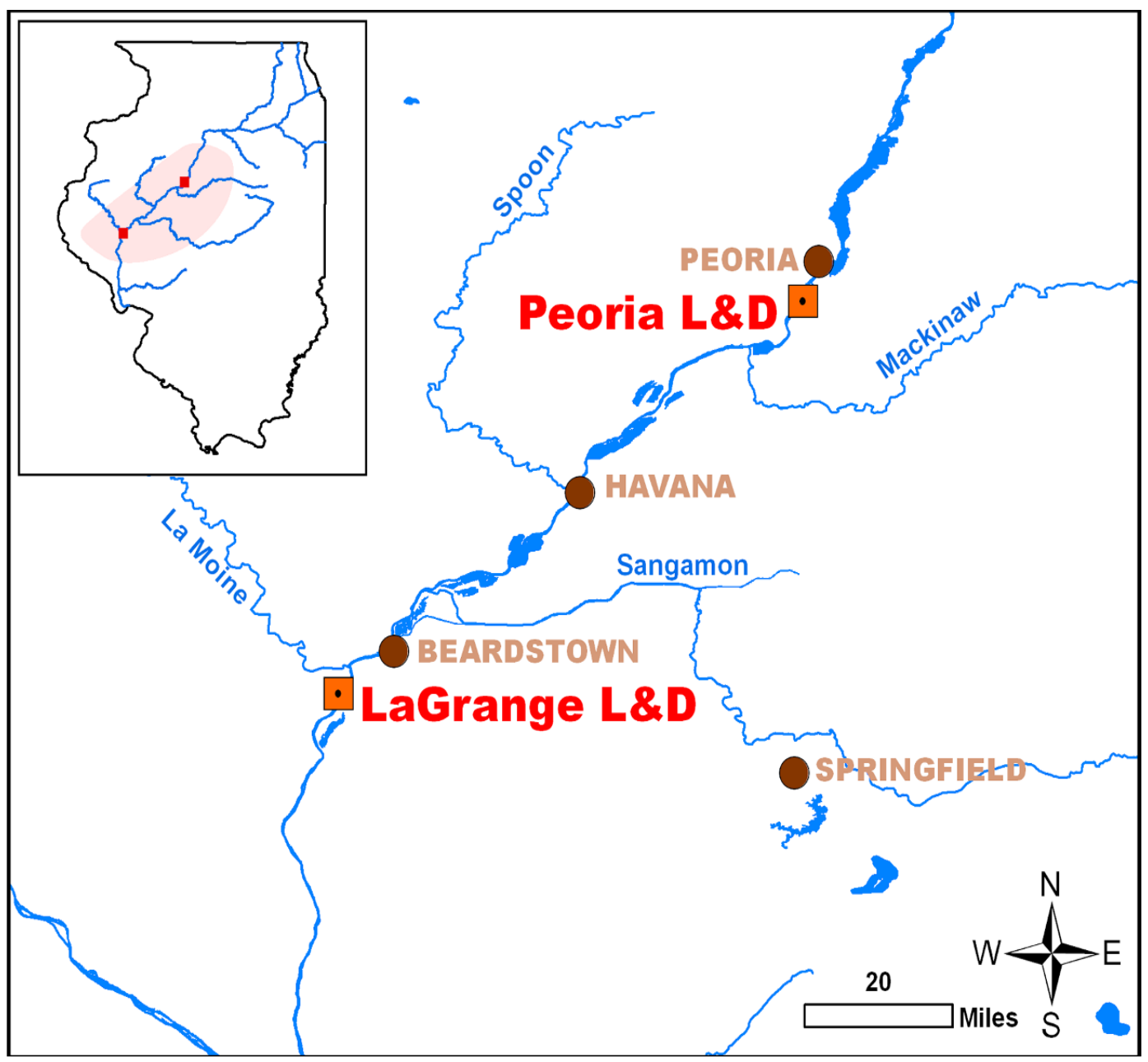

Figure 1. The La Grange Reach of the Illinois River stretches from its northern extent at the Peoria Lock and Dam at Peoria, Illinois to its southern extent at the La Grange Lock and Dam 8 miles downstream of Beardstown, Illinois.

Site selection-First- through third-order segments of streams connected directly to either the Illinois River or to one of four large tributaries of the Illinois River (LaMoine, Mackinaw, Sangamon, and Spoon Rivers) were identified using the DeLorme Gazetteer of Illinois (1996). Because bridge crossings offer easy access to streams, locations where public roads cross streams were chosen as potential sampling sites. A stratified random sampling method was used to select the final group of working sites.

The site selection process began with the identification of map locations representing first- through third-order streams within the study area; 169 locations were selected as potential sampling sites. These locations were then divided according to river connection, i.e. those connected directly to the Illinois River and those connected indirectly via the four smaller rivers listed above. The sites were further divided according to stream order, 
producing six categories-first- through third-order streams connected directly and first- through third-order streams connected indirectly to the Illinois River. Six sites were selected from each category for the final working group (Table 1).

Table 1. Sampling design for 2009 fieldwork. Six sites were randomly selected from each of six groups of candidate sites, making a total working group of 36 sampling sites.

\begin{tabular}{|l|l|l|}
\hline Stream Order & $\begin{array}{l}\text { Directly Connected to the } \\
\text { Illinois River }\end{array}$ & $\begin{array}{l}\text { Connected to Large Tributaries of } \\
\text { the Illinois River }\end{array}$ \\
\hline First-order streams & 6 & 6 \\
\hline Second-order streams & 6 & 6 \\
\hline Third-order streams & 6 & 6 \\
\hline
\end{tabular}

For the randomization process, all sites were entered into Microsoft Excel spreadsheets, and each category had its own worksheet. Using the command "=RANDBETWEEN(1,1000)," random numbers were assigned to each entry. Entries were sorted by the randomly assigned number from lowest to highest. The first six items on the list for each category were selected as the primary working sites. In the event that primary locations proved unworkable, secondary and tertiary groups of sites were selected from the sorted list in the same manner as the primary working group. Figure 2 shows the locations of all final working sites.

Field methods-For most small streams, a reach length of $100 \mathrm{~m}$ (roughly $300 \mathrm{ft}$ ) is sufficient to capture $90 \%$ of the species in a fish population in a single pass with electroshocking equipment (Patton et al. 2000). Thus, this was determined to be a sufficient length for a 1/ 8-in. mesh minnow seine when employing the Zippin depletion method (Lockwood and Schneider 2000, Zippin 1958) in an isolated stream segment.

Each location was divided into two sections. Transect A began $50 \mathrm{~m}$ downstream from the bridge and extended another $50 \mathrm{~m}$ further downstream. Transect $B$ began $50 \mathrm{~m}$ upstream from the bridge and extended another 50 $m$ further upstream. Thus, each site had an effective sampling distance of $100 \mathrm{~m}$, while the distance between transects allowed a sufficient buffer distance between sections to allow statistical treatment as two independent sample sites. 


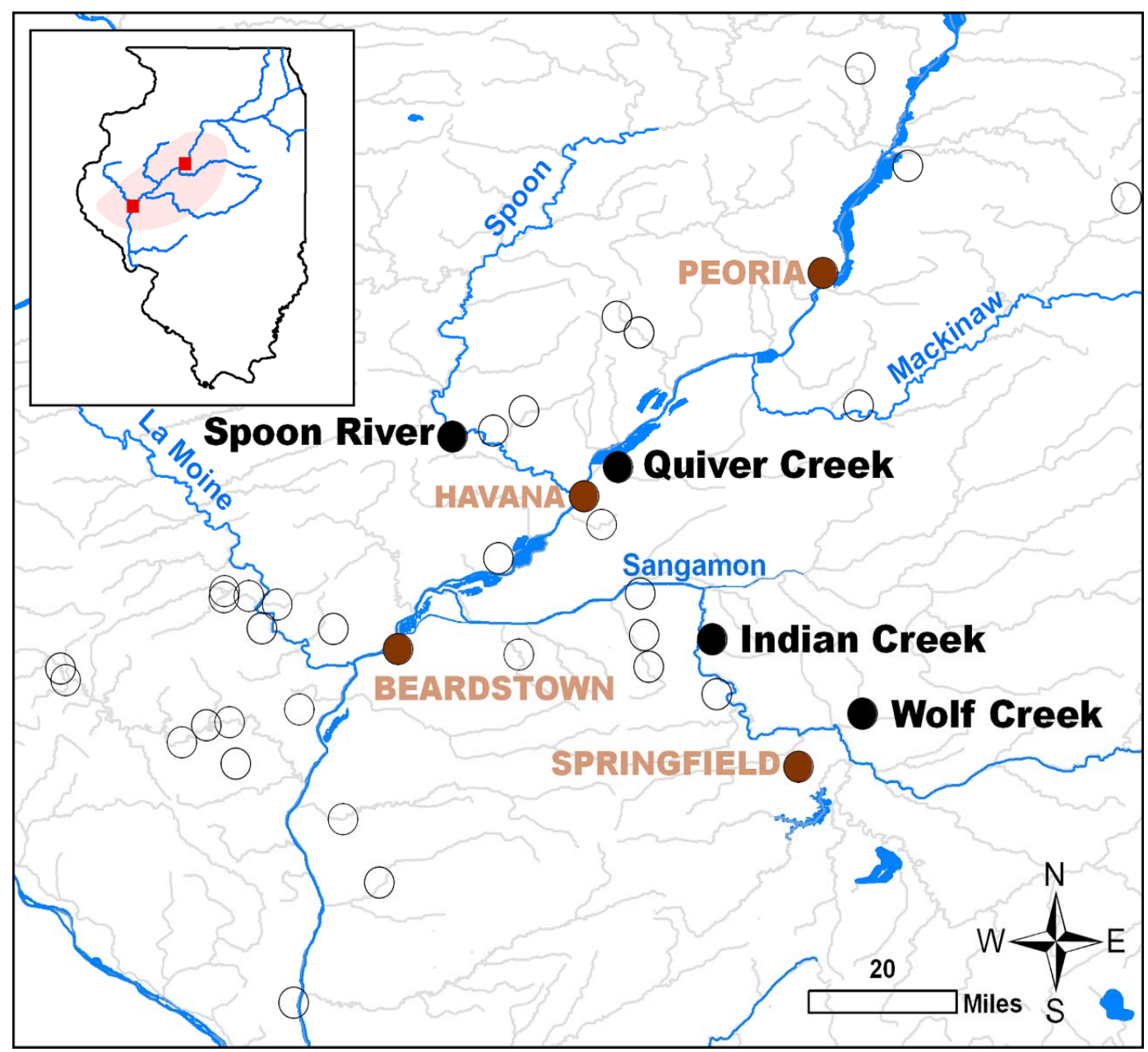

Figure 2. Locations of 2009 field sites. Open circles represent sampling sites. Closed black circles indicate sampling sites at which Asian carp were collected. Closed brown circles represent larger neighboring communities.

Beginning with Transect A (the downstream transect), each transect was isolated by block nets, erected first at the downstream extent and then at the upstream extent. Fish were collected with either a minnow seine or a bag seine. The entire length of each section was seined on each pass. The Zippin depletion method was used, in which successive passes were conducted until there were diminishing returns in the catch (i.e., significantly fewer individuals were being caught and no new species appeared). A minimum of three passes was completed per transect, but often as many as five passes were completed to reach the criteria for diminishing returns and thus ensure a representative sample of the species and numbers present in that stream at that location. There were two exceptions to this procedure. At both locations, standard seine hauls were rendered impossible due to the thick overgrowth of aquatic vegetation. In these instances, seine hauls were made where possible, but dip netting was used to supplement seining. 
Whenever possible, all fish collected were identified and released alive on the downstream side of the lower block net. Some individuals were euthanized in MS222 and preserved in formalin to be kept as voucher specimens. All carp specimens were preserved and kept as vouchers and for further study. All voucher specimens were deposited into the Illinois Natural History Survey Fish Collection when this study was completed.

Immediately prior to or following fish sampling, habitat data were collected, including mean stream width and thalweg depth, transect length and area, air and water temperature, water conductivity, turbidity (secchi depth), stream flow (speed of current), substrate, presence/ absence of aquatic vegetation, general weather conditions, and percentage of tree canopy cover. Substrate was categorized according to the following scale: Bedrock, Claypan, Silt-mud (<0.5 mm), Sand (0.6- $5 \mathrm{~mm}$ ), Gravel (6- $25 \mathrm{~mm}$ ), Cobble (26- $100 \mathrm{~mm}$ ), Boulder (>100 mm).

Analysis-Fish and habitat data obtained while sampling were subjected to Pearson correlation and logistic regression analysis to test for specieshabitat association, using SAS 9.1 statistical analysis software (SAS Institute 2004). All data were analyzed without transformation.

\section{Results}

Stream order-In 2009, 35 different sites were sampled (Figure 2). Ten sites were sampled between J une 25 and J uly 9, and 25 sites were sampled between August 31 and October 14. Many of the first-order streams originally selected were already dry by the beginning of the field season, so alternate sites were chosen to replace them. When the list of working and alternate first-order candidate sites was exhausted, second-, third-, and some newly selected (not randomly) fourth-order sites were used. Three sites were first-order, 14 were second-order, 11 were third-order, and seven were fourth-order (including the two sites from the previous year that were resampled). Because many first-order streams were already dry by the time field season began, field data are not as robust for this category as for others.

Fish-All sampled streams produced sufficient native species and individuals to indicate healthy fish populations, which in turn served to verify that the sampling methodology was sound. No bighead or silver carp were collected from any site. Five grass carps were detected at three sites-Indian Creek, Quiver Creek, and Wolf Creek (Table 2). All grass carps ranged in 
total length from 300-350 mm; therefore, all carp specimens collected were at least one year old but not breeding adults.

Table 2. Sampling sites at which Asian carps were located, including date, site, county, stream order, and species for each location.

\begin{tabular}{|l|l|l|l|l|l|}
\hline Date & Site & Order & County & Grass carp & Silver carp \\
\hline $09 / 01 / 2009$ & Indian Creek & 2 & Menard & 1 & 0 \\
\hline $09 / 03 / 2009$ & Wolf Creek & 3 & Sangamon & 2 & 0 \\
\hline $10 / 14 / 2009$ & Quiver Creek & 4 & Mason & 2 & 0 \\
\hline $10 / 08 / 20091$ & Spoon River & $5+$ & Fulton & 1 & 1 \\
\hline
\end{tabular}

${ }^{1}$ The Spoon River site is larger than fourth order, therefore it is not included in analysis. This sample was taken to verify that bighead and/or silver carp were where they were expected to be. This sample also served to prove that the sampling technique being used was effective for these species.

Habitat-Of the carp-producing sites, no two were in streams of equivalent order (Table 2). Figure 2 shows these sites relative to the study region. All sites are centrally located within the La Grange Pool area (Figure 2). Only Quiver Creek had any aquatic vegetation, which was in the form of flooded terrestrial plants (Figure 3, Table 3). Both Indian Creek and Wolf Creek had deeply incised channels with steep sides. The Indian Creek site was just off agricultural cropland in a residential area with $100 \%$ tree canopy cover (Figure 4), while Wolf Creek was surrounded by cornfields and had no canopy cover (Figure 5). Only the Quiver Creek site was connected to backwater floodplain areas. All sites had predominantly silt/ mud substrates. In these streams, conductivity ranged from $589-715 \mu \mathrm{mhos} / \mathrm{cm}$, turbidity 34.3- $43.2 \mathrm{in}$. (secchi depth), streamflow $9.0-23.2 \mathrm{sec} / \mathrm{m}$, and water temperature $10.0-18.4{ }^{\circ} \mathrm{C}\left(50-65^{\circ} \mathrm{F}\right)$ (Table 3$)$.

Species-habitat association-Since no bighead or silver carp were caught, statistical analysis could not be conducted for these two species. Pearson correlation analysis of grass carp presence with habitat variables returned significant results $(p<.05)$ for mean transect width and mean thalweg depth (Table 4). However, logistic regression returned no significant results for any habitat variable (Table 5).

\section{Discussion}

This investigation began with the hypothesis that Asian carps do not utilize small streams and the alternative hypothesis that they do. Basing hypotheses and fieldwork on existing records, it was expected that specimens 


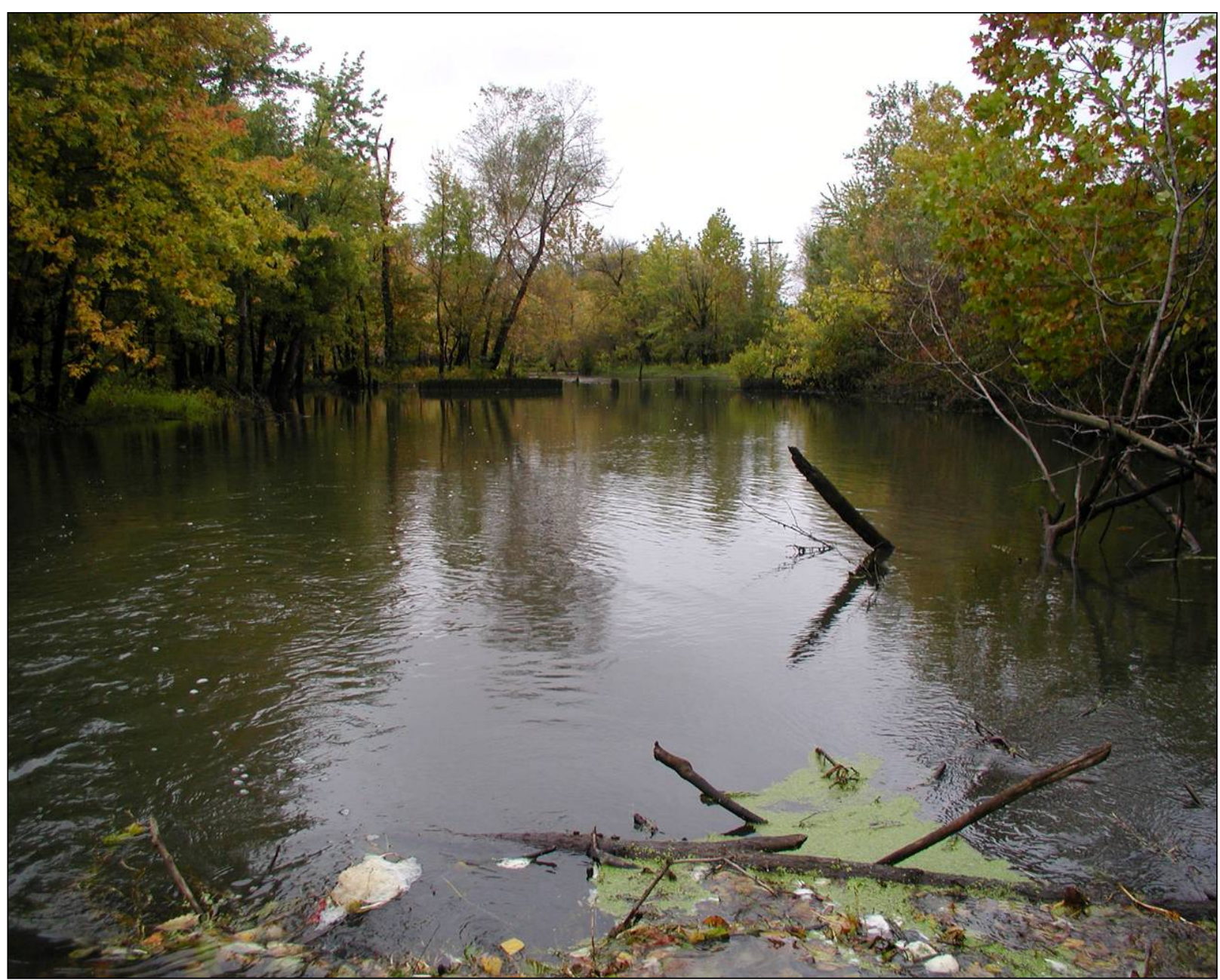

Figure 3. Quiver Creek sampling site. The Quiver Creek site was roughly $6.75 \mathrm{~km}$ from the Illinois River mainstem at the junction of two stream channels. This is a low-lying area that floods easily. As such, it could possibly serve as a nursery by Asian carp.

Table 3. Habitat characteristics of stream sites at which Asian carps were collected during 2009 fieldwork.

\begin{tabular}{|c|c|c|c|c|c|c|c|c|c|c|}
\hline Date & Site & $\begin{array}{l}\text { Air } \\
\text { Temp } \\
\text { (F) }\end{array}$ & $\begin{array}{l}\text { Water } \\
\text { Temp } \\
\text { (C) }\end{array}$ & $\begin{array}{l}\text { Conductivity } \\
\text { (umhos/cm) }\end{array}$ & $\begin{array}{l}\text { Turbidity } \\
\text { (secchi; } \\
\text { inches) }\end{array}$ & $\begin{array}{l}\text { Flow } \\
(\mathrm{sec} / \mathrm{m})\end{array}$ & $\begin{array}{l}\text { Mean } \\
\text { Width } \\
\text { (ft) }\end{array}$ & $\begin{array}{l}\text { Mean } \\
\text { Thalweg } \\
\text { Depth } \\
\text { (inches) }\end{array}$ & Substrate & Vegetation \\
\hline 09/01/09 & $\begin{array}{l}\text { Indian } \\
\text { Creek }\end{array}$ & 73 & 14.9 & 704 & 13.50 & 15.01 & 19.50 & 18.00 & $\begin{array}{l}\text { silt-mud, } \\
\text { claypan }\end{array}$ & none \\
\hline 09/03/09 & $\begin{array}{l}\text { Wolf } \\
\text { Creek }\end{array}$ & 67 & 18.4 & 715 & 13.50 & 23.20 & 22.00 & 26.00 & $\begin{array}{l}\text { silt-mud, } \\
\text { claypan }\end{array}$ & none \\
\hline 10/14/09 & $\begin{array}{l}\text { Quiver } \\
\text { Creek }\end{array}$ & 45 & 10.0 & 589 & 17.00 & 9.00 & 78.00 & 35.50 & silt-mud & $\begin{array}{l}\text { flooded } \\
\text { terrestrial }\end{array}$ \\
\hline
\end{tabular}




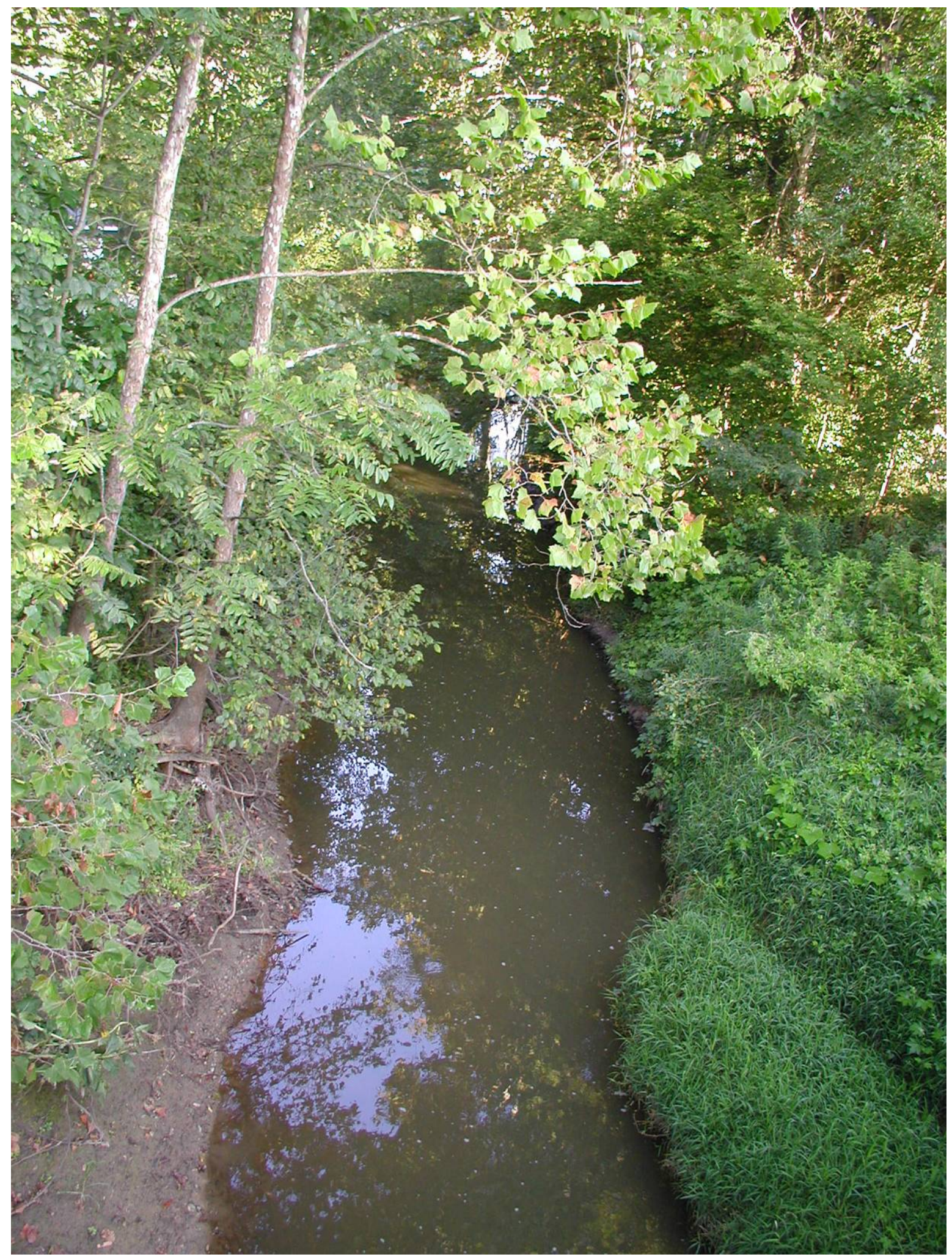

Figure 4. Indian Creek sampling site. The Indian Creek site was roughly $3.05 \mathrm{~km}$ from the Sangamon River and $74.15 \mathrm{~km}$ from the Illinois River mainstem. Primarily a system of agricultural ditches, Indian Creek has no backwater areas near the work site. 


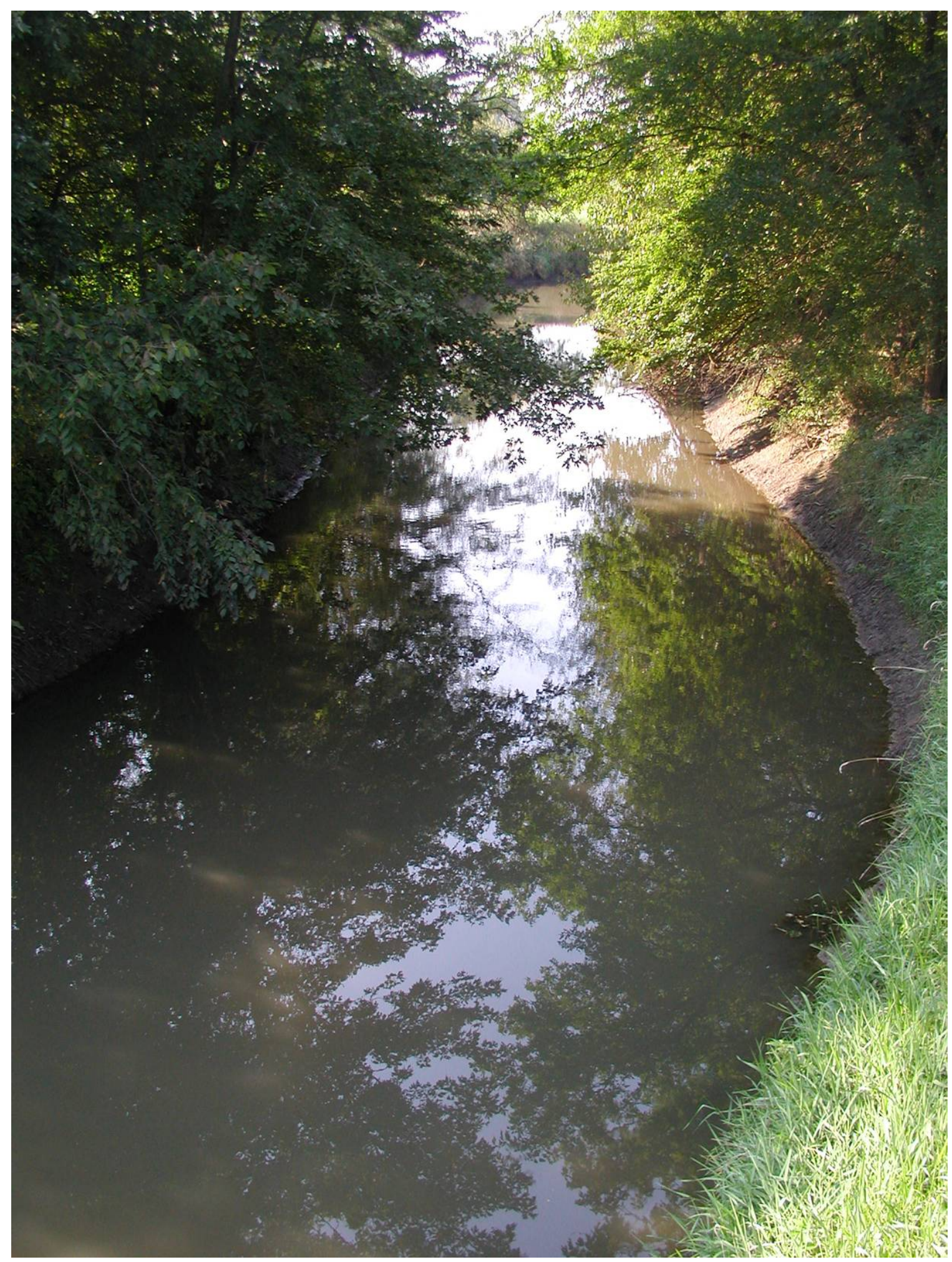

Figure 5. Wolf Creek sampling site. The Wolf Creek site was roughly $6.61 \mathrm{~km}$ from the Sangamon River and $119.20 \mathrm{~km}$ from the Illinois River mainstem. Primarily a system of agricultural ditches, Indian Creek has no backwater areas near the work site. 
Table 4. Results of Pearson correlation comparing habitat variables with presence of grass carp. Data used come from measurements taken during 2009 fieldwork. Results are considered significant if a $p$ value is $<0.05 .1$

\begin{tabular}{|l|l|l|}
\hline Parameter & Pearson Correlation Coefficients & Prob $>|\mathrm{r}|$ under HO: Rho=0 \\
\hline Water Temperature & -0.19175 & 0.1493 \\
\hline Conductivity & 0.04624 & 0.7304 \\
\hline Turbidity & -0.09408 & 0.4824 \\
\hline Flow & 0.22451 & 0.0902 \\
\hline Mean Transect Width & 0.53517 & $<.0001$ \\
\hline Mean Thalweg Depth & 0.38173 & 0.0031 \\
\hline
\end{tabular}

1The variables Water Temperature, Conductivity, Turbidity, Flow, Mean Transect Width, and Mean Thalweg Depth are continuous variables. The variables Stream Order, Claypan Substrate, Silt-Mud Substrate, Sand Substrate, Gravel Substrate, Cobble Substrate, Boulder Substrate, Bedrock Substrate, Emersed Aquatic Vegetation, Submersed Aquatic Vegetation, Flooded Terrestrial Vegetation, and Filamentous Algae are all categorical variables. Since Pearson correlation is meaningful only with continuous variables, the categorical variables were excluded from analysis with this method. All variables were included for logistic regression analysis (Table 5).

Table 5. Results of logistic regression comparing habitat variables with presence of grass carp. Data used come from measurements taken during 2009 fieldwork. Results are considered significant if a $p$-value is $<0.05$.

\begin{tabular}{|l|l|l|}
\hline Parameter & Maximum Likelihood Estimates P-value & Type 3 Analysis of Effects $P$-value \\
\hline Stream Order & 0.5814 & 0.5814 \\
\hline Water Temperature & 0.9578 & 0.9578 \\
\hline Conductivity & 0.9395 & 0.9395 \\
\hline Turbidity & 0.8581 & 0.8581 \\
\hline Flow & 0.9050 & 0.9050 \\
\hline Mean Transect Width & 0.9925 & 0.9925 \\
\hline Mean Thalweg Depth & 0.2958 & 0.2958 \\
\hline Claypan Substrate & 0.9457 & 0.9457 \\
\hline Silt-Mud Substrate & 0.9213 & 0.9213 \\
\hline Sand Substrate & 0.7401 & 0.7401 \\
\hline Gravel Substrate & 0.8566 & 0.8566 \\
\hline Cobble Substrate & 0.8565 & 0.8565 \\
\hline Boulder Substrate & 0.9361 & 0.9361 \\
\hline Bedrock Substrate & 0.9991 & 0.9991 \\
\hline Emersed Aquatic Vegetation & 0.9952 & 0.9952 \\
\hline Submersed Aquatic Vegetation & 0.9249 & 0.9249 \\
\hline Flooded Terrestrial Vegetation & 0.8982 & 0.8982 \\
\hline Filamentous Algae & 0.9111 & 0.9111 \\
\hline
\end{tabular}


would be collected from at least the locations where they were found previously. Not only were Asian carp not caught where they had been caught previously, but those that were collected constituted new records for those locations. In total, field sampling of 36 sites produced five grass carp. Because of the number and range of sites selected, the paucity of carp specimens collected cannot be attributed to mere chance-while all three species are known to be highly mobile, the odds are statistically very slim that carp specimens were simply missed. It would appear that these fish were not present in the small streams of this drainage system.

Field sampling began in late J une 2009 and was concluded in October of the same year, with a three-week interruption in early J uly. The first grass carp was not produced until September 1, which might suggest that these species had not had time to move into smaller streams when sampling began. This could be an indication that, while these species can be found in smaller streams, they may not be there all the time. How long they stay in one location or how they find their way into these smaller streams are questions that cannot be answered by this study. More appropriate investigations for these questions would be long-term monitoring of fixed sites or some form of telemetry study.

The sites where grass carp were caught ranged in stream order from $2^{\circ}$ to $5+0$ (Table 2). Based strictly on this result, one could argue that these species utilize streams all the way down to second order. However, as the statistical analysis indicates, stream size would be a better consideration than stream order for determining the range into which these species might infiltrate a system. To this end, the smallest stream segment in which grass carp were encountered had a mean width of $6.71 \mathrm{~m}$ and a mean thalweg depth of $46 \mathrm{~cm}$.

Statistical analysis of species-habitat association for grass carp returned significant results for stream width and depth, but not for any variables related to substrate, vegetation, or water quality. Thus, there is no indication from the field data that there is any habitat association for grass carp other than the size of the stream (i.e., grass carp are mostly likely to be found in streams with a mean width greater than $6.71 \mathrm{~m}$ and a mean depth greater than $46 \mathrm{~cm}$ ). However, this in itself could prove useful to control and monitoring efforts. In this case, management agencies might limit their efforts to streams with a minimum mean width of $6.71 \mathrm{~m}$ and a minimum mean thalweg depth of $46 \mathrm{~cm}$. 
Sampling of 36 sites produced a total of five Asian carp, the first of which was caught nine weeks into the field season. With such a low representation of target species, an eddy zone on the main channel of the Spoon River just below a small flood control dam at Bernadotte (Figure 2) was sampled using the same field methods as all other sites. This location produced one grass carp and one silver carp. While the Spoon River is outside the range of stream orders in the sampling profile, this catch was not included in the analysis. However, it serves as proof that silver carp were in the system during the sampling period.

Since fieldwork produced grass carp and silver carp, it is concluded that Asian carps do utilize small streams. This is supported by survey records from both the IDNR and the INHS (discussed in Chapter 2). However, because so few Asian carp specimens were collected, possible alternative explanations were considered. Capture avoidance (the ability to avoid nets, etc.) would not provide an explanation, since all three species were caught the previous year at sites revisited during this investigation and using the same techniques. Also, timing or seasonality cannot provide an answer, as the previous year's samples were taken during the same time period. Water quality (dissolved oxygen, etc.) or productivity (plankton, chlorophyll, etc.) might provide an explanation, but speculation cannot be supported as no water quality or productivity measurements were recorded. Mobility of species (the ease and rapidity with which a species can move from place to place) can be ruled out due to the number and range of sites sampled, which are large enough to ensure a representative sampling of the region. Therefore, it is concluded that fieldwork produced so few Asian carp because their densities in small tributaries are very low. It is further suspected that because of their highly mobile nature, any forays into the watershed by these species are only temporary.

Finally, since grass carp continue to be stocked in local lakes and ponds, there is no way to determine if the individuals caught during the 2009 field season were stocked escapees or naturally spawned. Also, genetic testing is not possible, as the specimens were fixed in formalin prior to being deposited into the INHS Fish Collection. 


\section{Comparison of Field Data to INHS and IDNR Survey Data}

\section{Introduction}

According to collection records from the Illinois Natural History Survey (INHS) and survey data from the Illinois Department of Natural Resources (IDNR), a bighead carp was caught in the Kankakee River in 1990. In 1998, grass carp were caught in both the Mackinaw and Spoon Rivers. The first silver carp record comes from Macoupin Creek near Rockbridge, Illinois, in 2001. Later records reflect the presence of all three species in smaller creeks and streams well away from the Illinois River. Additionally, the temporal progression of carp reconds in smaller streams suggests that these species may be spreading outward as the mainstem river population increases in density.

Based on this information, it was hypothesized that the presence of Asian carp in smaller streams is associated with the size of the population in the mainstem of the Illinois River. To test this hypothesis, field data were combined with historic and current survey data provided by the IDNR and LTRMP. Using annual catch averages (total catch divided by total number of samples), population trends of the Illinois River mainstem were compared to that of its tributaries. If an association exists for these species, then there should be a statistically significant correlation $(p<.05)$ between annual catch averages for the two populations at least from the time when the carp populations became well established in the La Grange Pool.

\section{Methods}

All three Asian carp species are represented in the data prior to the year 2000. However, since bighead and silver carp were not considered established in the Illinois River until 2000, analysis was conducted for two time periods: all data for the period of record and data for the 2000 through 2009 period.

Data collection-Specimen records for bighead, grass, and silver carp were gathered from the INHS Fish Collection. Then, with assistance from many people in the IDNR, survey data on Asian carp were obtained from IDNR sampling records for the La Grange Pool drainage area. LTRMP sampling 
data from the LTRMP website were also downloaded. Data from these sources were combined with the author's field data.

While there are other agencies with active and ongoing sampling programs in Illinois (e.g., the U.S. Environmental Protection Agency [USEPA], the U.S. Geological Survey [USGS], and the U.S. Fish and Wildlife Service [USFWS]), the three that were used contain very robust data and were readily accessible.

Graphic analysis of population trends-Annual catch averages (total number of individuals caught divided by total number of sites sampled) for the Illinois River mainstem and its associated tributaries were entered into Microsoft Excel spreadsheets. Using scatter plots and histograms, these averages were plotted against each other, with the resulting trend line representing overall growth, decline, or no change. All data for the period of record were analyzed.

Data analysis of population trends-Wilcoxon's signed-ranks test, Pearson correlation, and least squares regression (Sokal and Rohlf 1995, Ott and Longnecker 2001) were used to compare annual catch averages between mainstem river populations versus tributary populations. Results were considered significant for $p$-values of $<.05$. This analysis was performed only for the years 2000-2009.

\section{Results}

Graphic analysis (Figures 6- 8) indicates generally increasing population trends over the long term for all three species in both the Illinois River mainstem and its associated tributaries. With the exception of grass carp in 1997, all three species remain relatively stable at low numbers until 2000. From 2000 on, all three species show a dramatic growth in number along with fluctuating averages from year to year, including massive dieoffs of bighead and silver carp in 2006. Due to an unusual amount of rainfall, 2008 was a banner year for all species, which significantly extended the spawn, while the 2009 spawn suffered from a lack of sufficient rainfall. Figures 9-11 show the relationship between mainstem and tributary populations when compared linearly, placing the mainstem river population on the $\mathrm{X}$-axis and the tributary population on the Y-axis. All six charts (Figures 6-11) illustrate an unmistakable upward trend in both populations. 


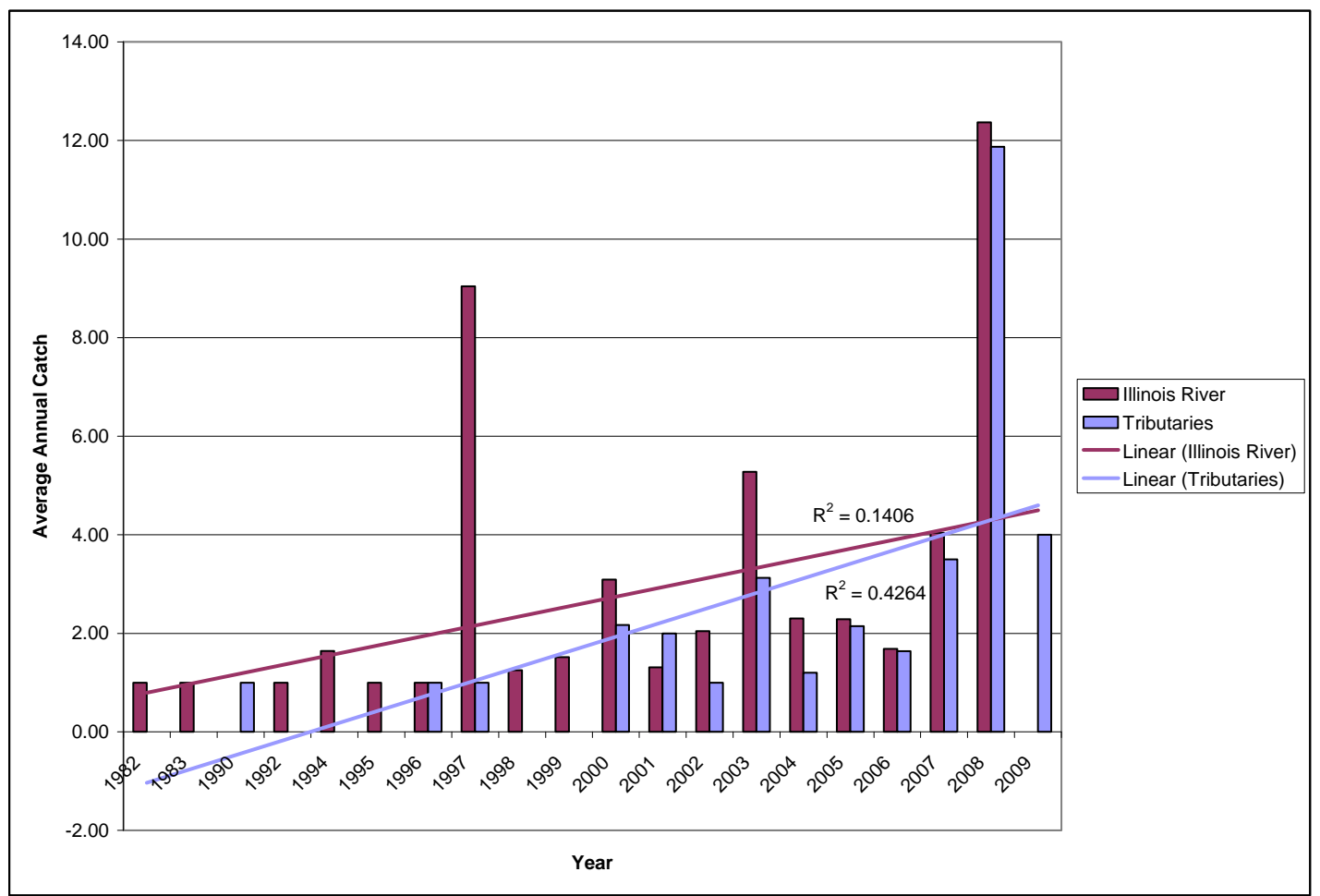

Figure 6. Histogram depicting average annual catch of grass carp in the Illinois River mainstem (maroon) and tributaries associated with the Illinois River (blue).

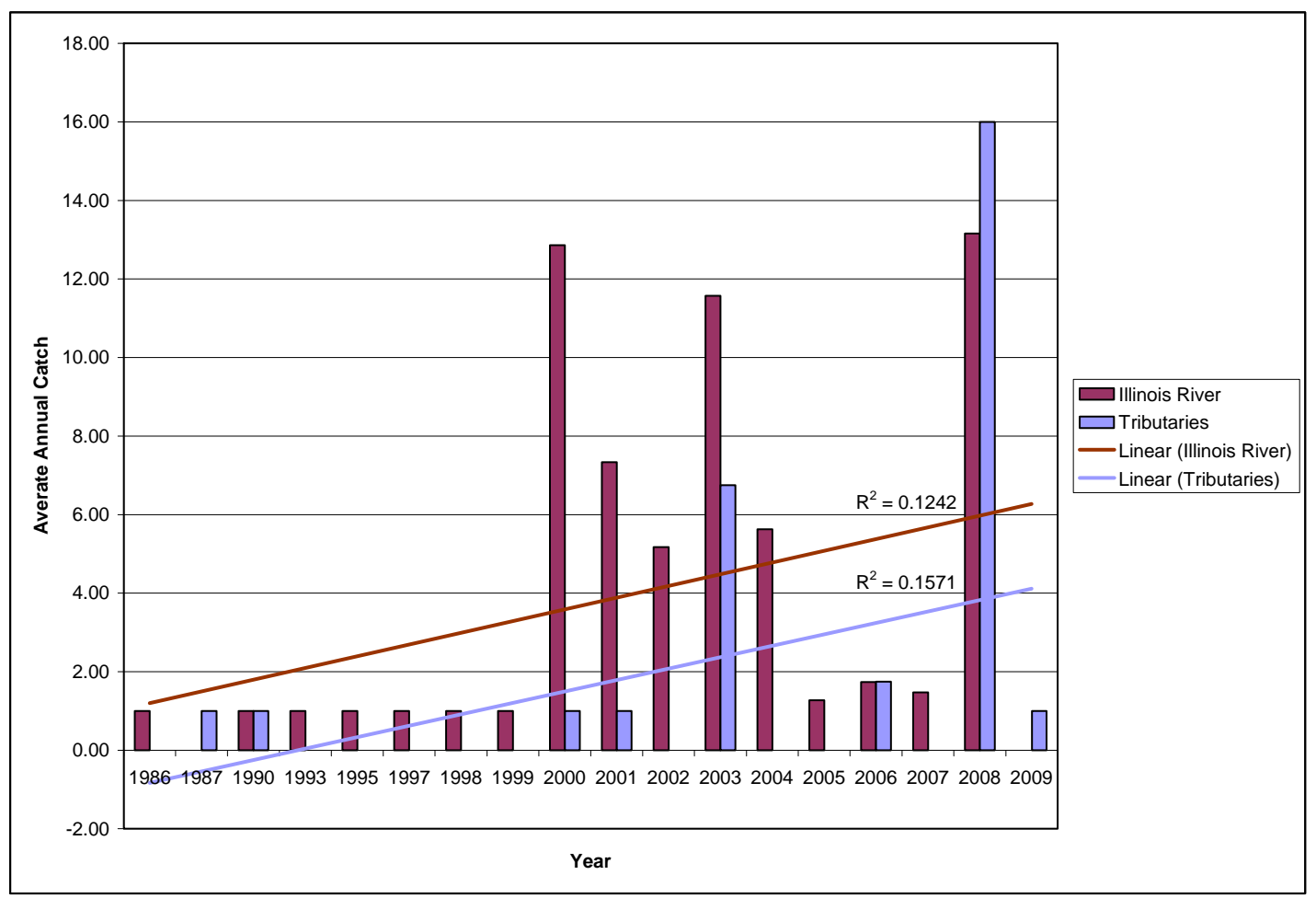

Figure 7. Histogram depicting average annual catch of bighead carp in the Illinois River mainstem (maroon) and tributaries associated with the Illinois River (blue). 


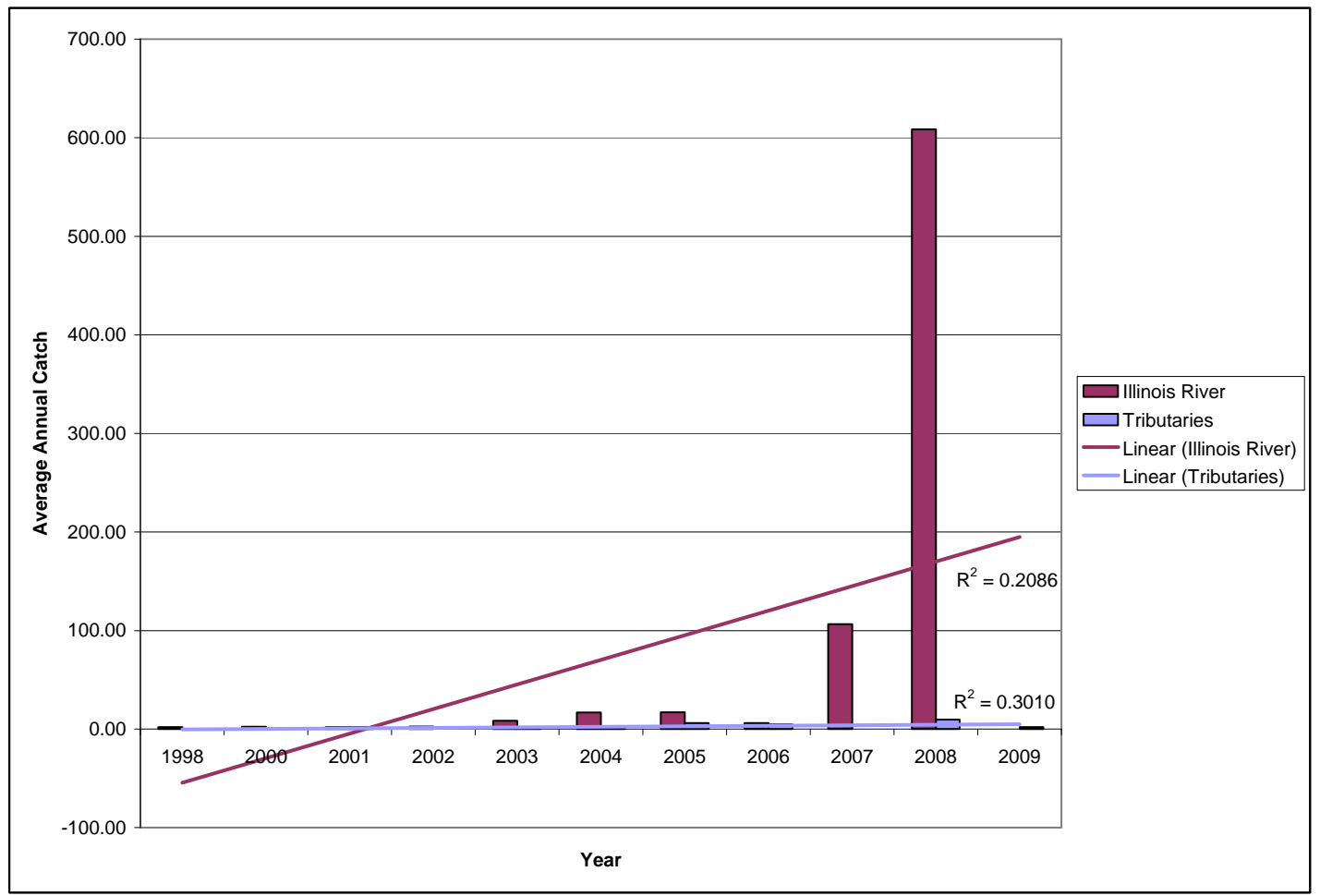

Figure 8. Histogram depicting average annual catch of silver carp in the Illinois River mainstem (maroon) and tributaries associated with the Illinois River (blue).

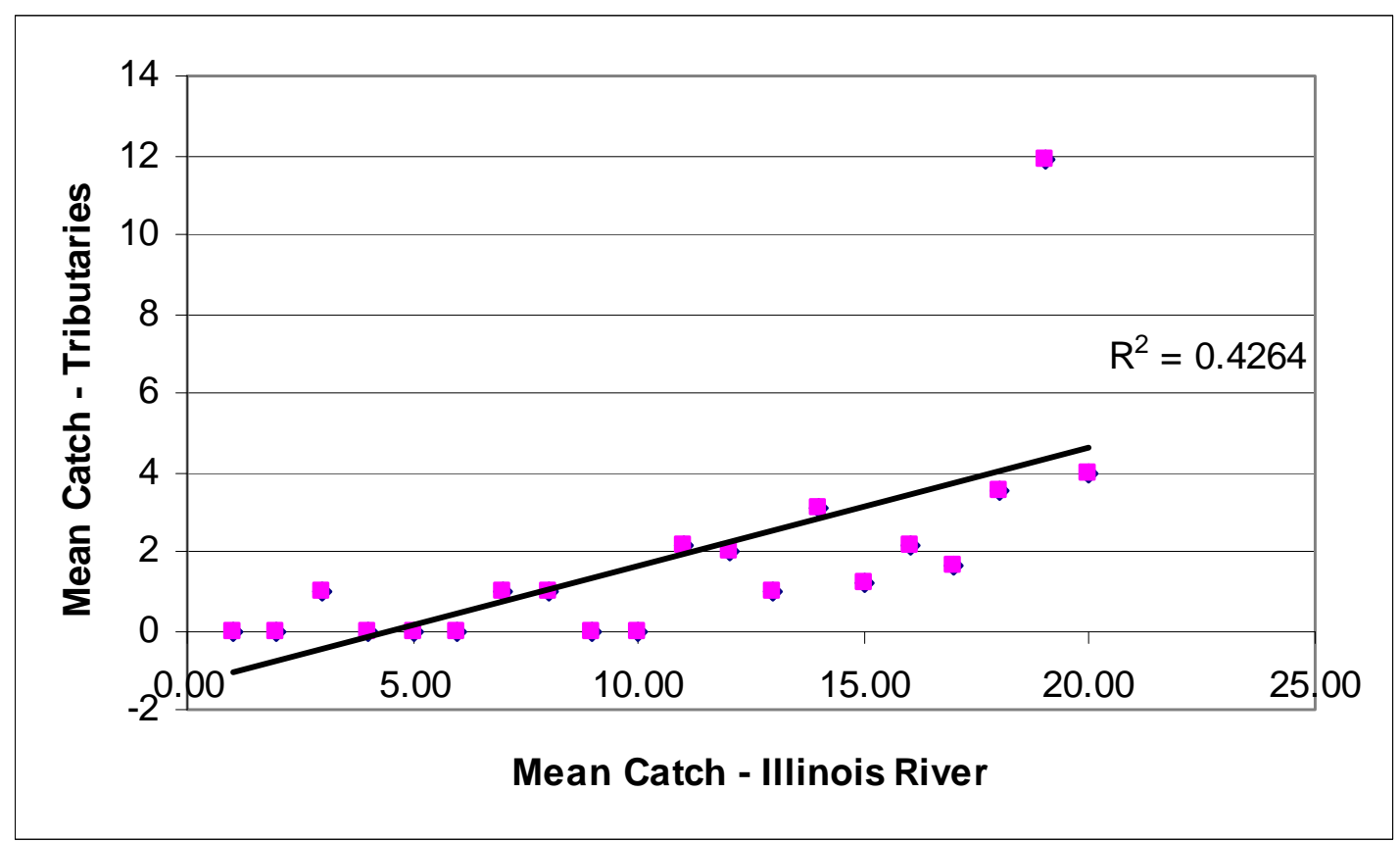

Figure 9. Scatter plot showing resulting trend line from charting average annual catch of grass carp in the Illinois River mainstem (X-axis) against average annual catch of grass carp in tributaries associated with the Illinois River (Y-axis). 


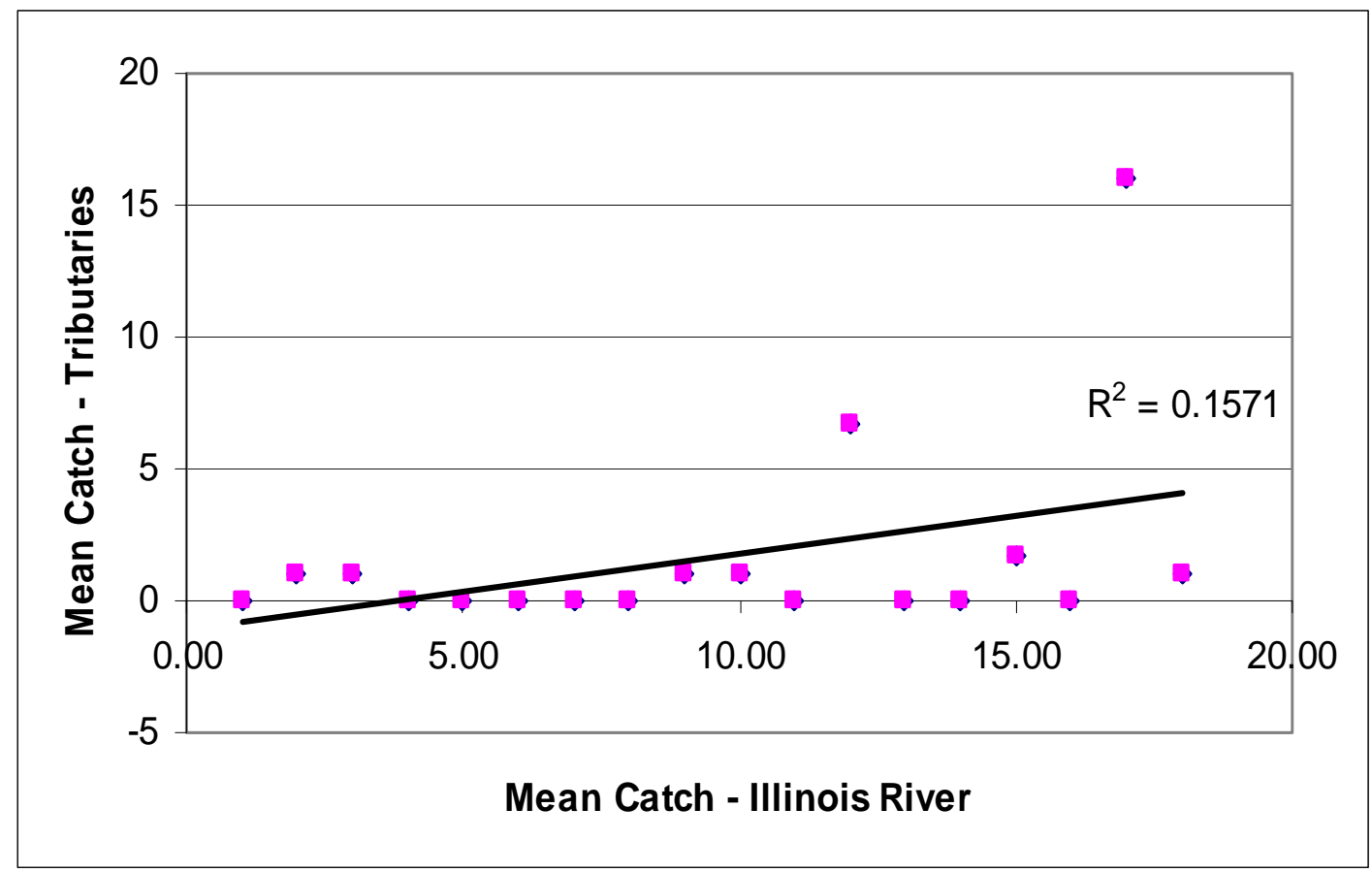

Figure 10. Scatter plot showing resulting trend line from charting average annual catch of bighead carp in the Illinois River mainstem (X-axis) against average annual catch of bighead carp in tributaries associated with the Illinois River (Y-axis).

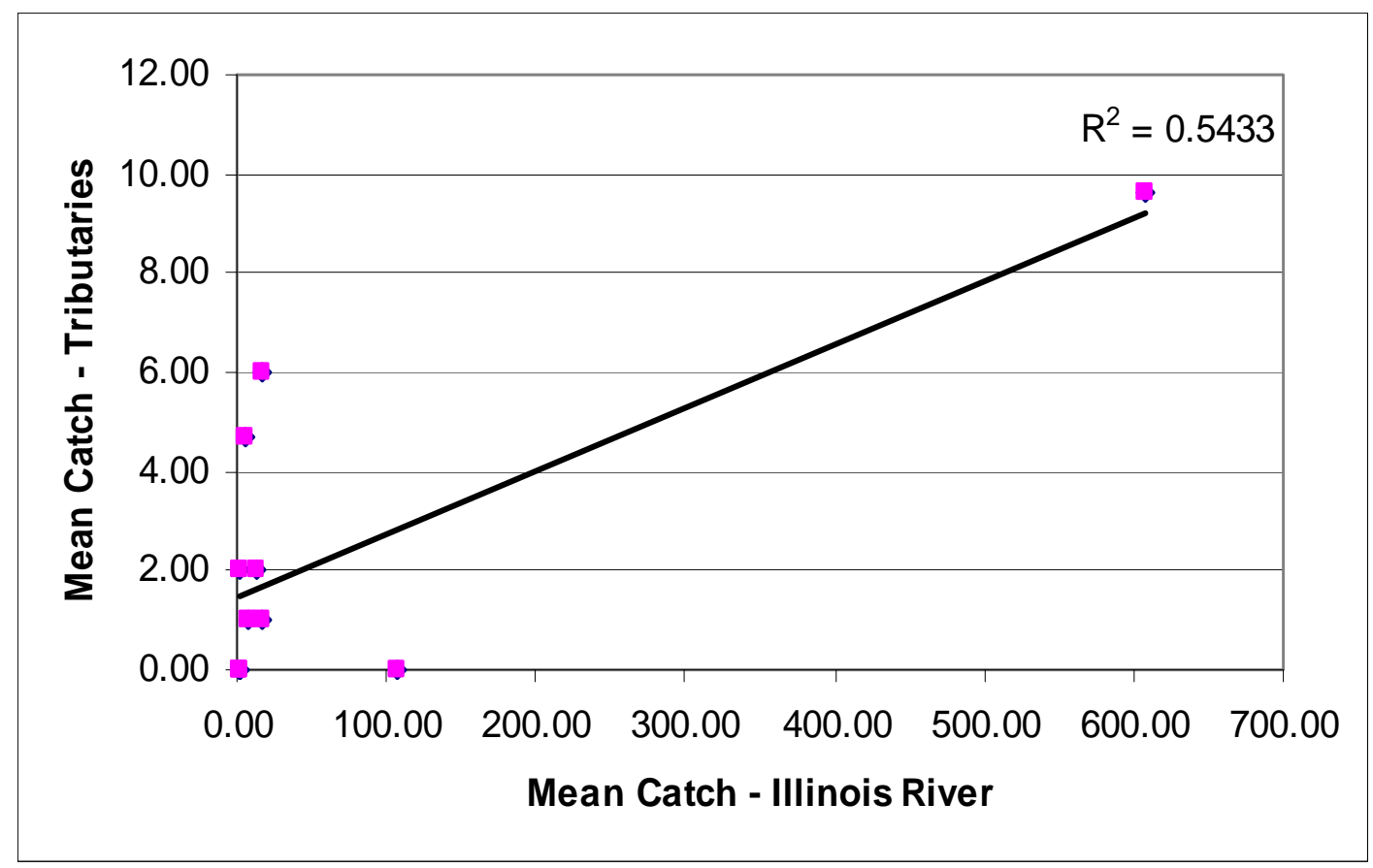

Figure 11. Scatter plot showing resulting trend line from charting average annual catch of silver carp in the Illinois River mainstem (X-axis) against average annual catch of silver carp in tributaries associated with the Illinois River (Y-axis). 
Wilcoxon's signed-ranks tests (Tables 6- 8) indicate a positive correlation between river and stream population trends for grass carp and silver carp from 2000 through 2009, but not for bighead carp. Pearson correlation and least squares regression analysis (Table 9 ) indicate that tributary population trends are significantly correlated $(p<.05)$ to population trends in the Illinois River mainstem for grass carp and silver carp, but not for bighead carp.

Table 6. Wilcoxon's signed-ranks test results from comparing annual grass carp population trends for the Illinois River mainstem versus its tributaries. Annual population trends are represented by annual average catch (total annual catch divided by total annual number of sampling sites). ${ }^{1}$

\begin{tabular}{|c|c|c|c|c|c|c|c|}
\hline \multicolumn{4}{|c|}{ Illinois River Mainstem } & \multicolumn{4}{|c|}{ Illinois River Tributaries } \\
\hline year & $\begin{array}{l}\text { catch/ } \\
\text { year }\end{array}$ & $\begin{array}{l}\text { samples/ } \\
\text { year }\end{array}$ & $\begin{array}{c}\text { avg. } \\
\text { catch/year }\end{array}$ & year & $\begin{array}{l}\text { catch/ } \\
\text { year }\end{array}$ & $\begin{array}{l}\text { samples/ } \\
\text { year }\end{array}$ & $\begin{array}{c}\text { avg. } \\
\text { catch/year }\end{array}$ \\
\hline 2000 & 309 & 100 & 3.09 & 2000 & 13 & 6 & 2.17 \\
\hline 2001 & 68 & 52 & 1.31 & 2001 & 6 & 3 & 2.00 \\
\hline 2002 & 47 & 23 & 2.04 & 2002 & 3 & 3 & 1.00 \\
\hline 2003 & 306 & 58 & 5.28 & 2003 & 25 & 8 & 3.13 \\
\hline 2004 & 106 & 46 & 2.30 & 2004 & 6 & 5 & 1.20 \\
\hline 2005 & 105 & 46 & 2.28 & 2005 & 15 & 7 & 2.14 \\
\hline 2006 & 69 & 41 & 1.68 & 2006 & 18 & 11 & 1.64 \\
\hline 2007 & 206 & 51 & 4.04 & 2007 & 7 & 2 & 3.50 \\
\hline 2008 & 643 & 52 & 12.37 & 2008 & 95 & 8 & 11.88 \\
\hline 2009 & 151 & 132 & 1.14 & 2009 & 4 & 1 & 4.00 \\
\hline year & \multicolumn{2}{|c|}{$\begin{array}{l}\text { river avg. } \\
\text { catch/year }\end{array}$} & $\begin{array}{c}\text { tributary avg. } \\
\text { catch/year }\end{array}$ & \multicolumn{2}{|c|}{$\begin{array}{c}\text { difference } \\
\text { (river - trib) }\end{array}$} & rank & \\
\hline 2000 & & 3.09 & 2.17 & & 0.92 & 7 & \\
\hline 2001 & & 1.31 & 2.00 & & -0.69 & -2 & \\
\hline 2002 & & 2.04 & 1.00 & & 1.04 & 8 & \\
\hline 2003 & & 5.28 & 3.13 & & 2.15 & 10 & \\
\hline 2004 & & 2.30 & 1.20 & & 1.10 & 9 & \\
\hline 2005 & & 2.28 & 2.14 & & 0.14 & 4 & \\
\hline 2006 & & 1.68 & 1.64 & & 0.05 & 3 & \\
\hline 2007 & & 4.04 & 3.50 & & 0.54 & 6 & \\
\hline 2008 & & 12.37 & 11.88 & & 0.49 & 5 & \\
\hline \multirow[t]{4}{*}{2009} & & 1.14 & 4.00 & & -2.86 & -1 & \\
\hline & & & & abs. & sum neg. & 2 & \\
\hline & & & & & sum pos. & 8 & \\
\hline & & & Critica & Value & $n=10, \xi$ & $\begin{array}{l}\mathrm{T}_{s}=2 \\
n=10 \\
=.005)=3\end{array}$ & \\
\hline
\end{tabular}

1For $n=10$ pairs and a confidence level of .005 , the critical value is 3 (Sokal and Rohlf 1995, Ott and Longnecker 2001). The T-value of 2 is equal to or less than the critical value and therefore is significant. There is sufficient evidence to reject the original hypothesis that river and tributary population trends are not correlated in favor of the alternative hypothesis that they are (Sokal and Rohlf, 1994, pp.443-444). Data provided by LTRMP, IDNR, INHS Fish Collection, and 2009 field data. 
Table 7. Wilcoxon's signed-ranks test from comparing annual bighead carp population trends for the Illinois River mainstem versus its tributaries. Annual population trends are represented by annual average catch (total annual catch divided by total annual number of sampling sites). ${ }^{1}$

\begin{tabular}{|r|r|r|r|}
\hline \multicolumn{4}{|c|}{ Illinois River Mainstem } \\
\hline year & $\begin{array}{c}\text { catch/ } \\
\text { year }\end{array}$ & $\begin{array}{l}\text { samples/ } \\
\text { year }\end{array}$ & $\begin{array}{c}\text { avg. } \\
\text { catch/year }\end{array}$ \\
\hline 2000 & 1235 & 96 & 12.86 \\
2001 & 675 & 92 & 7.34 \\
2002 & 181 & 35 & 5.17 \\
\hline 2003 & 324 & 28 & 11.57 \\
2004 & 225 & 40 & 5.63 \\
\hline 2005 & 28 & 22 & 1.27 \\
\hline 2006 & 26 & 15 & 1.73 \\
\hline 2007 & 28 & 19 & 1.47 \\
\hline 2008 & 566 & 43 & 13.16 \\
\hline 2009 & 73 & 132 & 0.55 \\
\hline
\end{tabular}

\begin{tabular}{|r|r|r|r|}
\hline \multicolumn{4}{|c|}{ Illinois River Tributaries } \\
\hline year & $\begin{array}{c}\text { catch/ } \\
\text { year }\end{array}$ & $\begin{array}{c}\text { samples/ } \\
\text { year }\end{array}$ & $\begin{array}{c}\text { avg. } \\
\text { catch/year }\end{array}$ \\
\hline 2000 & 1 & 1 & 1.00 \\
\hline 2001 & 1 & 1 & 1.00 \\
\hline 2002 &. &. &. \\
\hline 2003 & 27 & 4 & 6.75 \\
\hline 2004 &. &. &. \\
\hline 2005 &. &. & 1.75 \\
\hline 2006 & 7 & 4 &. \\
\hline 2007 &. & & 16.00 \\
\hline 2008 & 16 & 1 & 1.00 \\
\hline 2009 & 2 & 2 & \\
\hline
\end{tabular}

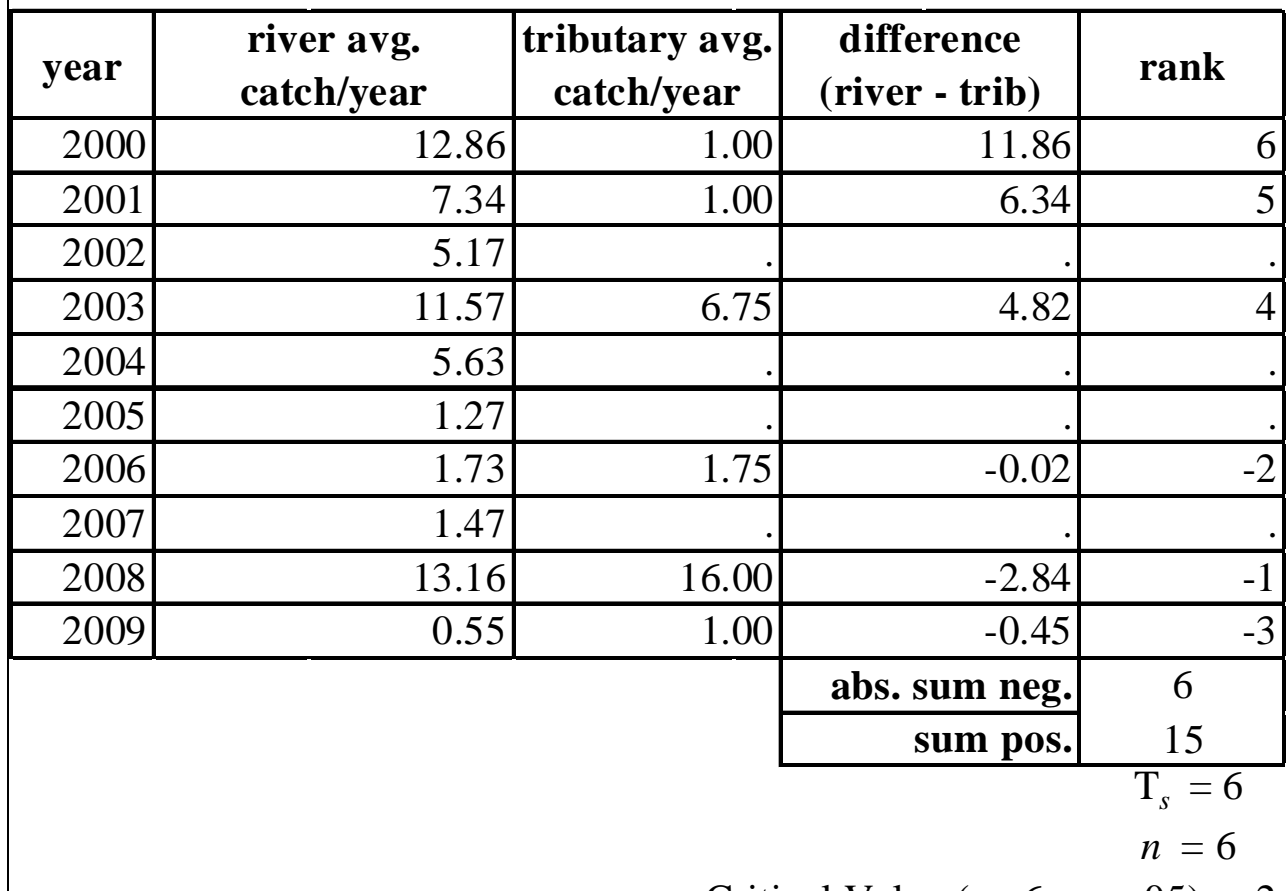

Critical Value $(n=6, \quad=.05)=2$

${ }^{1}$ For $n=6$ pairs and a confidence level of .05 , the critical value is 2 (Sokal and Rohlf 1995, Ott and Longnecker 2001). The T-value of 6 is greater than the critical value and therefore is not significant. There is not sufficient evidence to reject the original hypothesis that river and tributary population trends are not correlated in favor of the alternative hypothesis that they are (Sokal and Rohlf, 1995, pp.443-444). Data provided by LTRMP, IDNR, INHS Fish Collection, and 2009 field data. 
Table 8. Wilcoxon's signed-ranks test from comparing annual silver carp population trends for the lllinois River mainstem versus its tributaries. Annual population trends are represented by annual average catch (total annual catch divided by total annual number of sampling sites). ${ }^{1}$

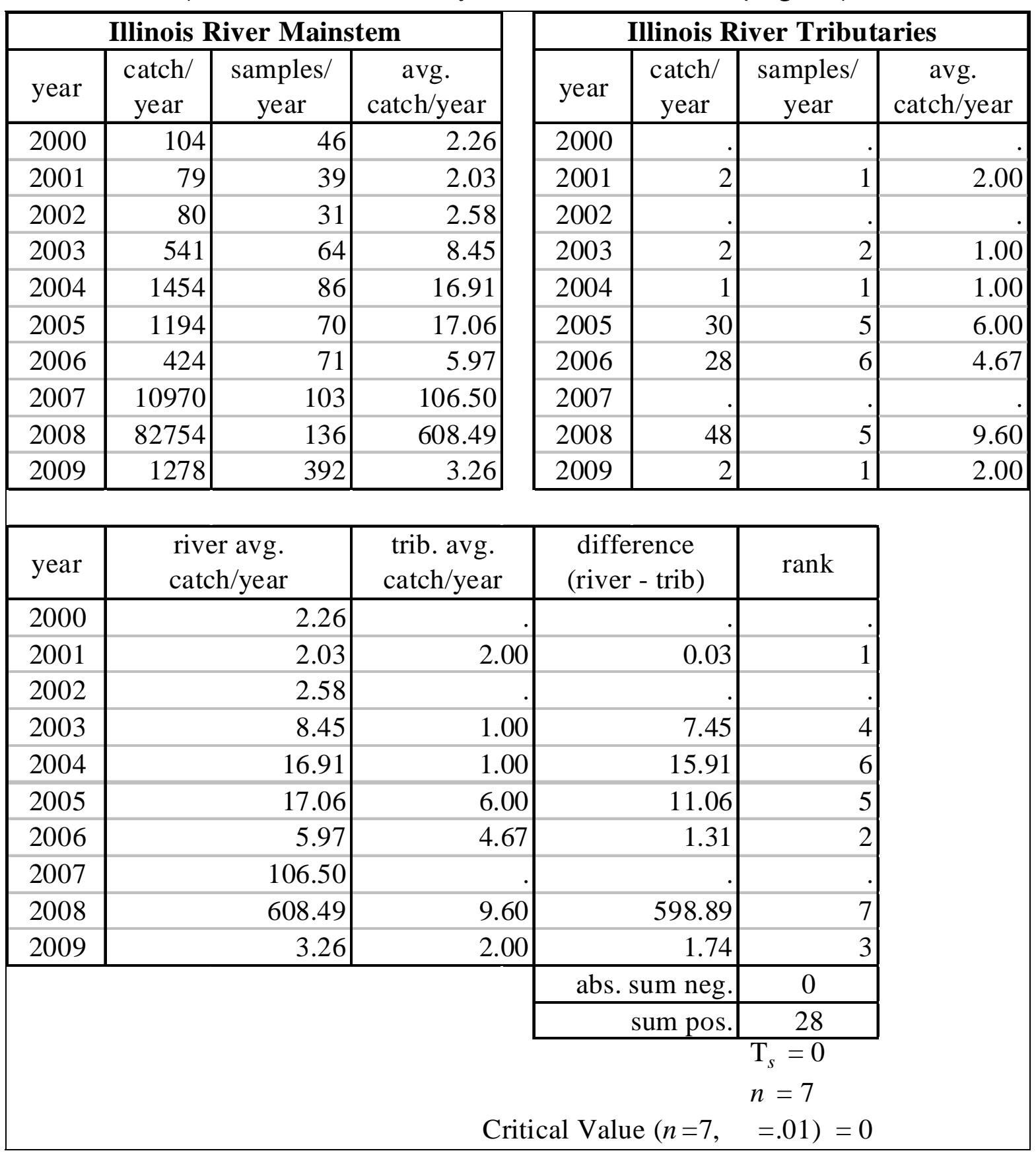

1For $n=7$ pairs and a confidence level of .01, the critical value is 0 (Sokal and Rohlf 1995, Ott and Longnecker 2001). The T-value of 0 is equal to or less than the critical value and therefore is significant. There is sufficient evidence to reject the original hypothesis that river and tributary population trends are not correlated in favor of the alternative hypothesis that they are correlated. (Sokal and Rohlf 1995, pp.443-444). Data provided by LTRMP, IDNR, INHS Fish Collection, and 2009 field data. 
Table 9. $p$-values returned from Pearson correlation and linear regression analysis comparing mainstem average annual catch numbers against tributary average annual catch numbers.

Results are considered significant if a $p$-value is $<0.05$.

\begin{tabular}{|l|l|l|}
\hline Species & Pearson correlation $p$-value & Linear regresson $p$-value \\
\hline Grass carp & 0.0067 & 0.0067 \\
\hline Bighead carp & 0.1540 & 0.1540 \\
\hline Silver carp & 0.0279 & 0.0279 \\
\hline
\end{tabular}

\section{Discussion}

Results indicate that stream and mainstem river population trends follow similar patterns. Pearson correlation and linear regression results agreed with Wilcoxon's signed-ranks test results for silver and grass carp, but only from 2000 to present. This suggests that stream utilization by these species did not occur with regularity until the river populations had become well established (around the year 2000). It is possible that mechanisms such as carrying capacity or density-dependent dispersal could provide an explanation for this phenomenon, but further research is needed to determine this.

Species-habitat association-Pearson correlation and logistic regression analysis of all combined data produced no significant results $(p<.05)$ common to both stream and mainstem river ecosystems for any Asian carp species relating to habitat. Correlation analysis of LTRMP data produced no significant results, and logistic regression exposed a complete lack of any associational relationship in my field data. Because of the lack of corroboration from statistical analysis of species-habitat associations, the current research does not indicate the action of any habitat-related mechanism driving the movement of these species between the Illinois River and its tributaries. Any such mechanisms that could be suggested by more robust habitat measurements-such as water quality, chemistry, or productivitycannot be addressed here, as measurements were limited to the most basic tools and techniques.

Stream trends versus river trends-This investigation shows that stream trends follow mainstem river trends for Asian carps in the LaGrange Reach of the Illinois River. Density-dependent dispersal (Murray 1967) and Ideal Free Distribution (Fretwell and Lucas 1970) have been confirmed as driving mechanisms for movement in other fish species (Hauzy et al. 2007, Blanchard et al. 2005, Keeley 2001, Tyler and Gilliam 1995). Thus, it is possible that these mechanisms could explain the movements of Asian carp 
species in and among Illinois River tributaries, especially if other potential explanations can be ruled out, but further research is needed in this area.

Summary-Results from this investigation support the hypothesis that Asian carp population trends in tributaries of the Illinois River are associated with population trends in the Illinois River mainstem. Based on these results, it is evident that population trends for the Illinois River mainstem drive population trends in tributaries for at least two of the species studied (grass carp and silver carp). Also, scores from statistical analysis ( $R$-values, correlation coefficients, error, etc.) improve as dates move closer to the present, suggesting that the relationship between stream and river populations became stronger as the river population increased over time. When combined with the fact that tests for specieshabitat associations returned nothing to suggest otherwise, the argument is strengthened that stream population trends are driven by river population trends.

Implications-The data for all three species reflect a general population increase throughout the LaGrange Pool drainage system over the long term, and all indications are that this will continue for the foreseeable future (Sass et al. 2010). While these findings do not suggest any permanent or ongoing residence in streams by Asian carp, they do indicate that stream usage continues to increase. As mainstem river populations continue to grow, more individuals will be forced to forage further away from the river. Not only is the ecosystem of the Illinois River mainstem being threatened, but the entire drainage system is in danger of degradation by these exotic invasive species. Therefore, according to these findings, control of the mainstem river population seems the best way to control stream populations. 


\section{References}

Blanchard, J. L., C. Mills, S. J ennings, C. J . Fox, B. D. Rackham, P. D. Eastwood, and C. M. O'Brien. 2005. Distribution- abundance relationships for North Sea Atlantic cod (Gadus morhua): Observation versus theory. Canadian Journal of Fisheries and Aquatic Science 62:2001-2009.

Fretwell, S. D., and H. L. Lucas. 1970. On territorial behavior and other factors influencing habitat distribution in birds. Acta Biotheoretica 19:136- 156.

Guillory, V., and R. D. Gasaway. 1978. Zoogeography of the grass carp in the United States. Transactions of the American Fisheries Society 107(1):105- 112.

Hauzy, C., F. D. Hulot, A. Gins, and M. Loreau. 2007. Intra- and interspecific densitydependent dispersal in an aquatic prey- predator system. Journal of Animal Ecology 76:552-558.

Irons, K. S., G. G. Sass, M. A. McClelland, and J . D. Stafford. 2007. Reduced condition factor of two native fish species coincident with invasion of non-native Asian carps in the Illinois River, U.S.A. Is this evidence for competition and reduced fitness? Journal of Fish Biology 71(Supplement D):258- 273.

J ennings, D. P. 1988. Bighead carp (Hypophthalmichthys nobilis): A biological synopsis. U.S. Fish and Wildlife Service Biological Report 88(29):1-47. Washington, DC: U.S. Fish and Wildlife Service.

J erde, C. L., A. R. Mahon, W. L. Chadderton, and D. M. Lodge. 2010. “Sight-unseen" detection of rare aquatic species using environmental DNA. Conservation Letters 00:1-8.

Keeley, E. R. 2001. Demographic responses to food and space competition by juvenile steelhead trout. Ecology 82(5):1247- 1259.

Kolar, C. S., D. C. Chapman, W. R. Courtenay, Jr., C. M. Housel, J . D. Williams, and D. P. J ennings. 2005. Asian carps of the genus Hypophthalmichthys (Pisces, Cyprinidae)-a biological synopsis and environmental risk assessment. Report to U.S. Fish and Wildlife Service.

Lockwood, R. N., and J . C. Schneider. 2000. Stream fish population estimate by markand- recapture depletion methods. In Manual of fisheries survey methods II: With periodic updates. Chapter 7, Fisheries Special Report 25, ed. J . C. Schneider. Ann Arbor, MI: Michigan Department of Natural Resources.

Meyer, J . L., D. L. Strayer, J . B. Wallace, S. L. Eggert, G. S. Helfman, and N. E. Leonard. 2007. The contribution of headwater streams to biodiversity in river networks. Journal of the American Water Resources Association 43(1):86- 103.

Minshall, G. W., R. C. Peterson, J r., and C. F. Nimz. 1985. Species richness in streams of different size from the same drainage basin. The American Naturalist 125(1):1638. 
Murray, B.G., Jr. 1967. Dispersal in vertebrates. Ecology 48(6):975- 978.

Ott, R. L., and M. T. Longnecker. 2001. An introduction to statistical methods and data analysis. $5^{\text {th }}$ ed. Pacific Grove, CA: Duxbury Press.

Patton, T. M., W. A. Hubert, F. J . Rahel, and K. G. Gerow. 2000. Effort needed to estimate species richness in small streams on the Great Plains in Wyoming. North American Journal of Fisheries Management 20:394- 398.

Resh, V. H., A. V. Brown, A. P. Covich, M. E. Gurtz, H. W. Li, G. W. Minshall, S. R. Reice, A. L. Shelden, J. B. Wallace, and R. C. Wissmar. 1988. The role of disturbance in stream ecology. Journal of the North American Benthological Society 7(4):433455.

SAS Institute Inc. 2004. SAS OnlineDoc® 9.1.3. Cary, NC.

Sass, G. G., T. R. Cook, K. S. Irons, M. A. MoClelland, N. N. Michaels, T. M. O’Hara, and M. R. Stroub. 2010. A mark-recapture population estimate for invasive silver carp (Hypophthalmichthys molitrix) in the La Grange Reach, Illinois River. Biological Invasions 12:433-435.

Schlosser, I. J . 1987. A conceptual framework for fish communities in small warmwater streams. In Community and evolutionary ecology of North American stream fishes, ed. W. J. Mathews and D. C. Heins, 17-32. Norman, OK: University of Oklahoma Press.

Schofield, P. J., J . D. Williams, L. G. Nico, P. Fuller, and M. R. Thomas. 2005. Foreign nonindigenous carps and minnows (Cyprinidae) in the United States-a guide to their identification, distribution, and biology. U.S. Geological Survey, Scientific Investigations Report 2005- 5041. Reston, VA: U.S. Geological Survey.

Shireman, J. V., and C. R. Smith. 1983. Synopsis of biological data on the grass carp, Ctenopharyngodon idella (Curvier \& Valenciennes, 1844). FAO Fish Synopsis 135, FIR/ S135.

Sokal, R. R., and F. J . Rohlf. 1995. Biometry: The principles and practice of statistics in biological research. $3^{\text {rd }}$ ed. New York: W. H. Freeman.

Townsend, C. R., M. R. Scarsbrook, and S. Doledec. 1997. The intermediate disturbance hypothesis, refugia, and biodiversity in streams. Limnology and Oceanography 42(5):938-949.

Tyler, J . A., and J . F. Gilliam. 1995. Ideal free distributions of stream fish: A model and test with minnows, Rhinichthys atratulas. Ecology 76(2):580-592.

Zippin, C. 1958. The removal method of population estimation. The Journal of Wildlife Management 22(1):82-90. 


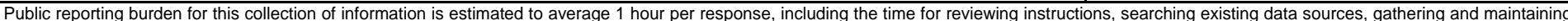

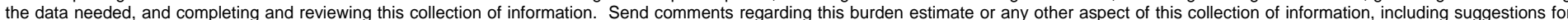

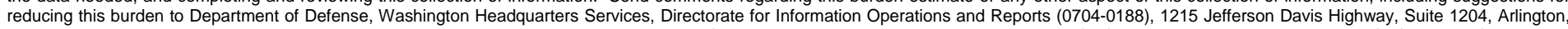

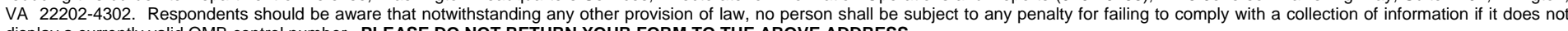
display a currently valid OMB control number. PLEASE DO NOT RETURN YOUR FORM TO THE ABOVE ADDRESS.
1. REPORT DATE (DD-MM-YYYY) 2. REPORT TYPE
3. DATES COVERED (From - To)

July 2012 Final

\section{TITLE AND SUBTITLE}

Habitat Preference, Dispersal, and Population Trends of Three Species of Invasive Asian Carps in Tributaries of the La Grange Reach of the Illinois River

5a. CONTRACT NUMBER

5b. GRANT NUMBER

5c. PROGRAM ELEMENT NUMBER

\section{AUTHOR(S)}

5d. PROJECT NUMBER

Michael R. Wilson

5e. TASK NUMBER

5f. WORK UNIT NUMBER

\section{PERFORMING ORGANIZATION NAME(S) AND ADDRESS(ES)}

Illinois Natural History Survey

University of Illinois at Urbana-Champaign

8. PERFORMING ORGANIZATION REPORT NUMBER

ERDC/EL CR-12-2

9. SPONSORING I MONITORING AGENCY NAME(S) AND ADDRESS(ES)

10. SPONSOR/MONITOR'S ACRONYM(S)

U.S. Army Engineer Research and Development Center

3909 Halls Ferry Road

Vicksburg, MS 39180-6199

11. SPONSOR/MONITOR'S REPORT NUMBER(S)

\section{DISTRIBUTION I AVAILABILITY STATEMENT}

Approved for public release; distribution is unlimited.

\section{SUPPLEMENTARY NOTES}

\section{ABSTRACT}

Asian carps (Ctenopharyngodon idella, Hypophthalmichthys molitrix, and H. nobilis), first introduced into the United States in the 1960s and 1970s, escaped and established reproducing populations in the Mississippi and Illinois River systems by the year 2000. By the mid 1990s, they were appearing in smaller tributaries and streams in Illinois. During the summer of 2009, a drainage-wide survey of the La Grange Reach of the Illinois River was conducted to determine the extent to which these species were utilizing first- through fourthorder streams in this system. Field sampling of 36 sites over a 33,636-km² area in 2009 produced a total of five grass carp and no other Asian carp specimens, indicating temporary nonresident utilization of small streams. Because of the paucity of Asian carp specimens collected during field work, field data were combined with records from the Illinois Natural History Survey Fish Collection, Illinois Department of Natural Resources survey data, and the Long Term Resource Monitoring Program. These data were subjected to statistical analysis to test for correlation of population trends between the Illinois River mainstem and its associated tributaries. Analysis results revealed a positive relationship between annual mainstem and tributary population trends for grass carp and silver carp, as well as a continually increasing population size for all three species in both mainstem and tributary populations.

\section{SUBJECT TERMS}

Asian carp

Illinois Natural History Survey Fish Collection

Illinois River

\section{SECURITY CLASSIFICATION OF:}

\begin{tabular}{l|r}
\hline a. REPORT & b. ABSTRACT \\
Unclassified & Unclassified
\end{tabular}

17. LIMITATION
OF ABSTRACT
Unclassified

La Grange Reach

\begin{tabular}{c|l}
$\begin{array}{c}\text { 18. NUMBER } \\
\text { OF PAGES }\end{array}$ & $\begin{array}{l}\text { 19a. NAME OF RESPONSIBLE } \\
\text { PERSON: Ty Wamsley }\end{array}$ \\
\cline { 2 - 2 } 34 & $\begin{array}{l}\text { 19b. TELEPHONE NUMBER (include } \\
\text { area code) }\end{array}$ \\
&
\end{tabular}

